\title{
28 Day Tablet Dosage Form
}

National Cancer Institute

\section{Source}

National Cancer Institute. 28 Day Tablet Dosage Form. NCI Thesaurus. Code C78747.

A drug pack that contains a 28 day supply of tablets, composed of a mixture of active and/or inert ing redient(s) that are pressed or compacted into a solid round, square or oval shaped form. 